\title{
COMPARISON OF THE TAX BURDEN OF A SELECTED TAXPAYER GROUP IN THE SLOVAK AND CZECH REPUBLICS Natália Stalmašeková ${ }^{1}$, Jana Štofková ${ }^{2}$, Tatiana Genzorová ${ }^{3}$
}

\begin{abstract}
The tax system is nowadays an important tool that can greatly influence the economy of every country. Its proper setup and the setup of all its parts is an extremely important task. This system has the task of raising funds for the state budget through the collection of taxes. The tax system is constantly evolving over time and adapts to the changing needs of the country. The aim of the paper is to compare the tax burden of a selected taxpayer group in the Slovak and Czech Republics. Part of the paper is an analysis of the conditions under which a taxpayer can benefit from a tax exemption and when he is required to pay contributions to the Social Insurance Company. The paper refers to the possibilities of advantageous application of tax rules to specific groups of taxpayers. The paper also includes specific examples of such situations.
\end{abstract}

JEL Classification Numbers: H24; DOI: http://dx.doi.org/10.12955/cbup.v6.1197

Keywords: Tax system, tax burden, state revenue.

\section{Introduction}

It is important to recognize that tax revenue accounts for the bulk of government revenue and finances the majority of public budget expenditures, and thus is of great importance for the functioning of the state as such. Schultzova (2011) defines the tax as a compulsory, statutory, non-equivalent, usually recurring payment that taxpayers pay to the state at a specified amount and within a set time. There are many different tax systems in the world that apply different principles and principles. There are many changes to tax systems, as a result of efforts to harmonize and standardize the European Union's tax systems, with measures to support the economy or to prevent tax evasion. However, the same measures do not produce the same results because each country is specific with its established tax system.

\section{Tax system}

"The tax system is one of the main areas of public finances. From an economic point of view, the tax is a tool for redistributing a national pension implemented through public budgets" (Štofkova et al., 2012). In each developed country with a functioning market economy, the tax system is one of the pillars of operation. In order to ensure harmony between executive bodies and citizens (in this case we mean specific tradesmen), the tax burden should not exceed a certain limit. Below this limit, of course, there is no intangible variable, but the "E" point on the Laffer curve. Determining effective tax rates is a very complicated process in which the interests of the state stand against its efforts to determine the tax rates as high as possible and the interests of the population and the business sector that seek to minimize the tax burden (Medved et al, 2005).

The main objective of the tax policy of the economic unit is tax optimization. In essence, it is the use of all legal ways to reduce taxes and levies as a whole, which should be done in keeping with the credibility of the company. (Landa, 2007). In analyzing the tax burden on economic subjects, we can come to terms with the tax impact.

Burak (2011) divides the system on:

a) legal - economic entity has the obligation to pay the tax to the relevant tax administrator in the statutory amount and time,

b) real - tells about the real tax burden on the taxpayer.

\section{Data and methodology}

The authors chose a segment of students as a selected segment of taxpayers. A comparison of students' tax burden in the Slovak Republic and the Czech Republic was created on the basis of the analysis of

\footnotetext{
${ }^{1}$ Faculty of Operation and Economics of Transport and Communications, University of Žilina, Slovak Republic, natalia stalmasekova@fpedas.uniza.sk.

${ }^{2}$ Faculty of Operation and Economics of Transport and Communications, University of Žilina, Slovak Republic, jana.stofkova@fpedas.uniza.sk

${ }^{3}$ Faculty of Operation and Economics of Transport and Communications, University of Žilina, Slovak Republic, tatiana.genzorova@fpedas.uniza.sk
} 
secondary data. The paper refers to the possibilities of advantageous application of tax rules to specific groups of taxpayers. The paper also includes specific examples of such situations.

\section{Results and discussion}

At first, we need to define agreements performed outside the employment relationship and identify the most convenient one for the students in Slovak Republic. The comparison is shown in Table 1.

\begin{tabular}{|c|c|c|c|}
\hline & $\begin{array}{c}\text { Agreement on Work } \\
\text { Activities }\end{array}$ & Agreement of service & $\begin{array}{c}\text { Agreement on students' } \\
\text { brigade work }\end{array}$ \\
\hline Who can deal with? & Person aged 15 or over & Person aged 15 or over & $\begin{array}{l}\text { A high school student } \\
\text { aged } 15 \text { or a college } \\
\text { student with a full-time } \\
\text { study of less than } 26 \text { years }\end{array}$ \\
\hline $\begin{array}{c}\text { When can the } \\
\text { agreement be used? }\end{array}$ & $\begin{array}{l}\text { Covering the } \\
\text { extraordinary needs of the } \\
\text { employer by one-off / } \\
\text { temporary work, which is } \\
\text { defined as a type of } \\
\text { continuously carried out } \\
\text { activity }\end{array}$ & $\begin{array}{c}\text { Covering the } \\
\text { extraordinary needs of } \\
\text { the employer by one- } \\
\text { off / temporary work as } \\
\text { defined by the result of } \\
\text { the activity }\end{array}$ & $\begin{array}{l}\text { Covering the } \\
\text { extraordinary needs of the } \\
\text { employer by one-off / } \\
\text { temporary work, which is } \\
\text { defined as a type of } \\
\text { continuously carried out } \\
\text { activity }\end{array}$ \\
\hline $\begin{array}{l}\text { How many hours } \\
\text { can an employee } \\
\text { work on a deal? }\end{array}$ & 10 hours a week & $\begin{array}{c}350 \text { hours in } 1 \text { calendar } \\
\text { year }\end{array}$ & $\begin{array}{c}20 \text { hours a week on } \\
\text { average, with a longer } \\
\text { contract duration of } 40 \\
\text { hours a week }\end{array}$ \\
\hline $\begin{array}{l}\text { How long can the } \\
\text { agreement be } \\
\text { concluded? }\end{array}$ & 12 months & 12 months & 12 months \\
\hline Income tax & $19 \%$ & $19 \%$ & $19 \%$ \\
\hline $\begin{array}{l}\text { Does the employer } \\
\text { have an obligation to } \\
\text { provide an employee } \\
\text { with at least a } \\
\text { minimum wage? }\end{array}$ & $\begin{array}{l}\text { Yes, at least EUR } 2.50 \\
\text { per hour }\end{array}$ & $\begin{array}{c}\text { Yes, at least EUR } 2.50 \\
\text { per hour }\end{array}$ & $\begin{array}{c}\text { Yes, at least EUR } 2.50 \text { per } \\
\text { hour }\end{array}$ \\
\hline $\begin{array}{l}\text { What is the amount } \\
\text { of employer's health } \\
\text { insurance payments } \\
\text { for a given type of } \\
\text { agreement? }\end{array}$ & $10 \%$ & $10 \%$ & $0 \%$ \\
\hline $\begin{array}{l}\text { What is the amount } \\
\text { of employer's social } \\
\text { contributions for a } \\
\text { given type of } \\
\text { agreement? }\end{array}$ & $25,2 \%$ & $\begin{array}{l}22,80 \% \text { for irregular } \\
\text { remuneration and } \\
25,20 \% \text { for regular } \\
\text { remuneration }\end{array}$ & $\begin{array}{l}22.80 \% \text { with an average } \\
\text { monthly income above } \\
200 \text { EUR or } 0 \% \text { with an } \\
\text { average monthly income } \\
\text { of up to } 200 \text { EUR and } \\
\text { application of the } \\
\text { exemption. }\end{array}$ \\
\hline
\end{tabular}

One of the reasons why agreement on student brigade work is the most advantageous is the lowest payout burden. In this section we will explain when the tax exemption is deducted from the student, and also when his / her tax burden is on the other hand.

The student has the right to a $200 €$ exemption from the tax, which he can only apply for this type of agreement. A tax exemption means that if a student earns less than $€ 200$ in a given month, he / she is not required to pay social insurance. If a student earns more than $€ 200$, only a part of the earnings that exceeded this limit apply. A student working on an agreement for student brigade work does not pay advances to a health insurance company. 
As already mentioned, a student can apply for a social security exemption of $€ 200$. If his / her earnings exceed this limit, the contributions to the Social Insurance Company shall be payable only for an amount exceeding $€ 200$. In this case, the student pays $4 \%$ of his retirement pension for old-age insurance and 3\% for sickness insurance, a total of $7 \%$.

Student income tax is calculated as: (gross remuneration - contributions to the social insurance company - non-taxable portion of the tax base) $\mathrm{x}$ tax rate $19 \%$ or $25 \%$ depending on the amount of the tax base. If the student's income is less than $€ 316.94$ and the student claims a non-taxable portion, his tax advance will be zero (Gasova \& Repkova Stofkova, 2016).

\section{Example:}

Andrea has an agreement for student brigade work. From the start of the agreement, she applies for a tax exemption and a non-taxable portion of the tax base. In January, her income was $170 €$, in February $200 €$, in March $280 €$ and in April $450 €$. In January or in February, she did not pay any social security contributions because her income was less than or equal to $€ 200$. For the month of March, she had to pay tax on $€ 80$ (€280 - $€ 200)$.

Old age and disability insurance contributions together account for $7 \%$, of which $€ 80$ represents $€ €$ 5.60. In April, Andrea earned $€ 450$ and hence had to pay social security contributions of $17,50 €(450$ $€-200 €=250 €, 7 \%$ from $250 €=17,50 €)$. The partial tax base after deduction of the levy is $€$ 432.50. Andrea has a signed declaration to claim a non-taxable portion of the tax base, so she can claim a non-taxable portion of $€ 316.94$. The tax base is then $€ 115.56$. From this amount, Andrea pays $19 \%$ of the income tax advance, which is $21.95 €$

If a student earned a total taxable income of less than $€ 1,901.67$ in 2017 and had deducted from his income tax deductions, he may voluntarily file a tax return, giving him a tax overcharge. This tax overpayment will be refunded to the tax administrator on the basis of a tax rebate request that is part of the tax return.

The tax surcharge will only be refunded if it is more than 5 euros. If this tax is less than 5 euros, no refund is claimed (Financna sprava, 2018).

\section{Czech Republic}

In Table 2 we definine the agreements performed outside the employment relationship for students in the Czech Republic.

\begin{tabular}{|c|c|c|}
\hline \multicolumn{3}{|l|}{ Table 2: Comparison of agreements } \\
\hline & Agreement of service & Agreement on Work Activities \\
\hline Income tax & $15 \%$ & $15 \%$ \\
\hline Health insurance & from $10001 \mathrm{CZK} /$ month. & from $2500 \mathrm{CZK} /$ month. \\
\hline Social insurance & from $10001 \mathrm{CZK} / \mathrm{month}$. & from $2500 \mathrm{CZK} /$ month. \\
\hline Maximum range of work performance & 300 hour /year & 20 hour /week \\
\hline Source: Authors (2018) & \multicolumn{2}{|l}{} \\
\hline
\end{tabular}

If the monthly remuneration from the work performance agreement does not exceed 10,000 CZK, earnings are not deducted from health insurance or social insurance, which is an immense advantage for both the employee and the employer. The same applies if a student earns up to 10,000 CZK for several employers at once. If several employment agreements are signed with one employer, the limit of 10,000 CZK applies for the sum of the monthly earnings. When it is higher, health and social insurance (including sickness insurance) are deducted from the whole amount.

If the monthly remuneration (or their sum per employer) exceeds $10000 \mathrm{CZK}$, the employer will always deduct $15 \%$ of the income tax prepayment. In this case, the tax is already calculated from the super-gross wage, which is the gross wage increased by the health insurance and social insurance payments paid by the employer to the student. When he signs a tax return with the employer, the employer will apply the discount to which he is entitled when calculating the tax (Penize, 2017).

For an employment agreement or for a work performance agreement, some provisions are not applicable for working on a standard employment contract, on legislation on severance pay, on working time and on rest, leave or termination of employment. 
The law in the Czech Republic allows students to benefit from certain tax benefits under the predefined conditions - such an advantage is in practice called the "tax allowance". Students can benefit from this allowance under certain conditions and additionally get back some of their taxes from the state. Since the student is expected to work only for a fraction of the year, he can still take advantage of a full taxpayer's allowance because he or she is eligible for the full year regardless of whether the student or anyone else worked shorter than the whole year.

As we have already mentioned, working students are entitled to apply for a tax to reduce the income tax on individuals. The student discount is one of the tax deductions that students can expect from a future job. There is no impact on the student's calculation of social insurance and health insurance. When calculating the mandatory premium, the discounts do not apply. For the use of this discount, a form called a taxpayer's statement, in practice often referred to as "pink paper", has to be signed by the employee to the employer when the employee is employed. It is important that in one calendar month this form can be signed and applied only to one employer (Studentmag, 2016).

Students up to 26 years old are entitled to a student tax credit of CZK 4020 for the entire calendar year. Students are also eligible for a discount on a student. Together with the basic discount on the taxpayer, to which everyone is entitled, the annual discount of the students is $28860 \mathrm{CZK}$ (24 840 $\mathrm{CZK}+4020 \mathrm{CZK})$. When calculating the monthly net wage, the tax deduction is $335 \mathrm{CZK}$ for the student. A payroll accountant must receive a school certificate. Lastly, the student's rebate can be applied for the month when the age of 26 is reached (in the case of full-time studies in doctoral programs, this can be up to the age of 28) (Finance, 2016).

Exceptions when a student is not entitled to this discount are:

- Distance, evening or combined study at secondary (non-high) schools if he / she is gainfully employed at the time of such studies (except for so-called agreements) or is entitled to unemployment or re-qualification at the time of such studies.

- Length of service (normal employment does not matter).

Occasionally, students only apply for a student discount but forgot to sign up for a (basic) taxpayer discount. They are entitled to both. Optional discounts - they do not interfere with each other but add up.

\section{Practical example: How much does a student save on taxes}

Student Lenka of Zilina University in Zilina was in business the whole year. Gross profit (income expense) for the year 2016 will be 234,400 CZK. The personal income tax is CZK 35,160 (CZK $234,400 \times 15 \%)$. After applying a taxpayer rebate of CZK 24,840 and a student rebate of CZK 4,020, the personal income tax for the whole year 2016 is CZK 6,300. If Lenka did not study, she would pay CZK 10,320 for income tax in 2016, or CZK 4,020 more.

Student discounts can also be applied to the work agreements. When students work in the summer months gradually for more than one employer, the tax declaration can be signed for only one employer for the same period. When working for two employers at the same time for an employment agreement, it is possible to apply for a tax declaration and therefore the tax rebate to only one employer.

If some students meet the study condition for only part of the year, they graduate from high school or college, so their annual retirement or tax return includes a rebate for the student in the first months of 2016 (although these students did not work during the study and conclude the contract after the study).

Practical example: Completion of the study and discount on the student

Student Lenka successfully completed her statehood in May 2017. She starts working on a contract of employment from 1 August 2017. In June and July, she has no income. When calculating the net monthly wage in August and the following months of 2017, a student's rebate cannot be applied because she was no longer a student. However, in the annual settlement for 2017, the taxpayer will reimburse CZK 24,840 in addition to the basic discount for the student for the months from January to July, ie in the amount of CZK 2,345 (CZK 335 x 7 months). If she had only started work since 1 September, then she would have been left as a student in August, but then over the last holidays she would not have been employed in the insurance business. (Financne, 2017) 
Therefore, the obligation arises if, in addition to tax-exempt income, or subject to withholding tax under a special tax rate (for example, dividends from the Czech Republic, income from dependent activity subject to withholding tax) - additional income higher than 15000 crowns per year. Employees also submit a tax return if they have income from one or more jobs simultaneously (not consecutively), and if their income from business or employment exceeds 6,000 crowns per year. The student must submit the tax return even if he / she has a loss of business.

\section{Conclusion}

The goal of the paper was to compare the differences, advantages and disadvantages that students have in individual employment relationships in both countries in terms of the tax burden.

As we have noticed, despite the fact that Slovakia and the Czech Republic have been in the past a united country, their tax systems vary considerably. Each state adapts tax laws to its budgetary policy.

We can say that the Czech Republic is more convenient for students in terms of taxes. Students will be able to use the student's discount on the pre-determined conditions in addition to the basic discount for the taxpayer. Similarly, there is a higher income tax rate in Slovakia and fewer possibilities to reduce the tax burden.

\section{References}

Štofková, J., Repková Štofková, K., Kastanek, P. (2015). Finance, Dolis, s.r.o. 152 p.

Schultzová, A. (2011). Daňovníctvo. Daňová teória a politika I. Bratislava: Iura edition. 260 p.

Medved', J. et al.(2005) Verejné financie. Bratislava: SPRINT. 163 p.

Burák, E. (2016). Daňovníctvo. Daňová teória, daňová politika a daňové riziká 1. vyd. Trenčín: Inštitút aplikovaného manažmentu, $201 \mathrm{p}$.

Landa, M. (2007). Finanční plánovaní a likvidita. Brno: Computer Press, 267 p.

Gasova, K. \& Repkova Stofkova, K. (2017) Comparison of the tax burden on natural persons in the Slovak

Republic and Spain. In: Proceedings of the 14th International Scientific Conference, pt 1, Brno, Czech Republic. Pp 135-142.

FINANCNASPRAVA (2018). Povinnost' študenta podat' daňové priznanie. Retrieved from

https://www.financnasprava.sk/sk/obcania/dane/dan-z-prijmov/studenti\#PovinnostStudentaPodatDP/

STUDENTMAG (2016). Student jako OSVČ a sociální pojištění. Kdy ho musíte platit a kdy ne? Retrieved from https://studentmag.topzine.cz/student-jako-osvc-a-socialni-pojisteni-kdy-ho-musite-platit-a-kdy-ne/.

FINANCE (2017). Sleva na studenta v 7 bodech. Retrieved from https://www.finance.cz/zpravy/finance/468912-sleva-nastudenta-v-sedmi-bodech/\#cast2

FINANCE (2016). Studenti, spočítejte si příjem z brigád. Retrieved from https://www.finance.cz/zpravy/finance/313809studenti-spocitejte-si-prijem-z-brigad/

PENÍZE (2017). Dohoda o provedení práce a dohoda o pracovní činnosti 2017: Přehled a kalkulačka odvodů. Retrieved from https://www.penize.cz/zamestnani/319917-dohoda-o-provedeni-prace-a-dohoda-o-pracovni-cinnosti-2017-prehled-akalkulacka-odvodu 